\title{
The use of induced sputum to investigate airway inflammation
}

\author{
I D Pavord, M M M Pizzichini, E Pizzichini, F E Hargreave
}

Clinicians have been interested in the macroscopic and microscopic appearance of sputum in asthma since the last half of the 19th century when Charcot-Leyden crystals, Curschmann's spirals, and their association with sputum eosinophilia was first recognised in patients with asthma. ${ }^{1}$ Forty years ago Morrow Brown suggested that the microscopic examination of sputum might be clinically useful by showing that the presence of eosinophils in a crude Leishman stained sputum smear identified patients whose wheeze was responsive to corticosteroids. ${ }^{2}$ Recently, with the recognition that even mild asthma is associated with evidence of airway mucosal inflammation in bronchial biopsy specimens and bronchoalveolar lavage fluid, ${ }^{34}$ there has been renewed interest in the use of sputum to assess airway inflammation non-invasively.

This review describes the development over the last eight years of new and reliable techniques to assess airway inflammation using sputum differential cell counts and measurement of molecular markers of inflammation in the sputum fluid phase. We review studies where these measurements have been made in normal and diseased subjects and assess their validity, repeatability, and responsiveness. Finally we describe current, and speculate on future, applications of sputum measurements of airway inflammation in asthma in both research and clinical settings.

\section{Developments in methodology}

Early attempts to provide reliable sputum differential cell counts used smears of spontaneously produced sputum stained with May-Grunwald-Giemsa. ${ }^{5}$ Additional staining with toluidine blue was required for accurate metachromatic cell counts. Salivary contamination was minimised by careful selection of sputum plugs and a total cell count was performed after cell dispersion with trypsin. Sputum total and differential cell counts were found to be repeatable between different plugs from the same specimen and between different specimens from the same subject. ${ }^{5}$ The sputum eosinophil and metachromatic cell count was considerably higher in subjects with asthma than in those with chronic bronchitis ${ }^{5}$ and was responsive to change as indicated by a $4-5$ fold increase 32 hours after allergen challenge in subjects with atopic asthma. ${ }^{6}$ However, the technique had important limitations. There was difficulty obtaining adequate sputum samples from some subjects, ${ }^{78}$ cell identification was difficult such that additional staining with chromotrope $2 \mathrm{R}$ was sometimes necessary to distinguish eosinophils from neutrophils, ${ }^{8}$ the investigation was time consuming, and the measurements were limited to total and differential cell counts. ${ }^{89}$

Two important innovations have largely overcome these problems. The first is the use of ultrasonically nebulised hypertonic saline to facilitate sputum production. ${ }^{7}$ The mechanism by which hypertonic saline induces sputum is incompletely understood but may involve increased outward water flux across the airway epithelium, stimulation of cough receptors and, perhaps, direct stimulation of the mucociliary escalator. ${ }^{10}$ In our hands a relatively quick protocol (fig 1), based on that described by Pin $e t a l^{7}$ using a relatively low output ultrasonic nebuliser (output $0.9 \mathrm{ml} /$ min, particle size $5.6 \mu \mathrm{m}$ ), results in successful sputum induction in $76 \%$ of normal and asthmatic subjects who cannot produce sputum spontaneously. Cell counts and biochemical content of induced and spontaneous sputum are similar with the exception of fibrinogen which is present in higher concentrations in spontaneous sputum. ${ }^{11}$ With salbutamol premedication and careful monitoring of forced expiratory volume in one second $\left(\mathrm{FEV}_{1}\right)$ during sputum induction in mild asthma significant bronchoconstriction rarely occurs, ${ }^{7}$ but it is more common in patients with more severe or uncontrolled asthma. ${ }^{12}$ In a recent study a third of sputum inductions in patients with asthma exacerbations who were overusing inhaled $\beta_{2}$ agonists were complicated by a $>10 \%$ fall in $\mathrm{FEV}_{1}$ which emphasises the need to perform the inductions carefully. ${ }^{12}$ We and other investigators have induced sputum in asthma using similar concentrations of hypertonic saline delivered by ultrasonic nebulisers with a higher output and, whilst there might be a higher success rate, this is at the expense of increased adverse effects including mild bronchoconstriction. ${ }^{13-15}$

A recent preliminary report has suggested that the cellular and biochemical content of sputum induced by a high output ultrasonic nebuliser changes with sequential inhala-

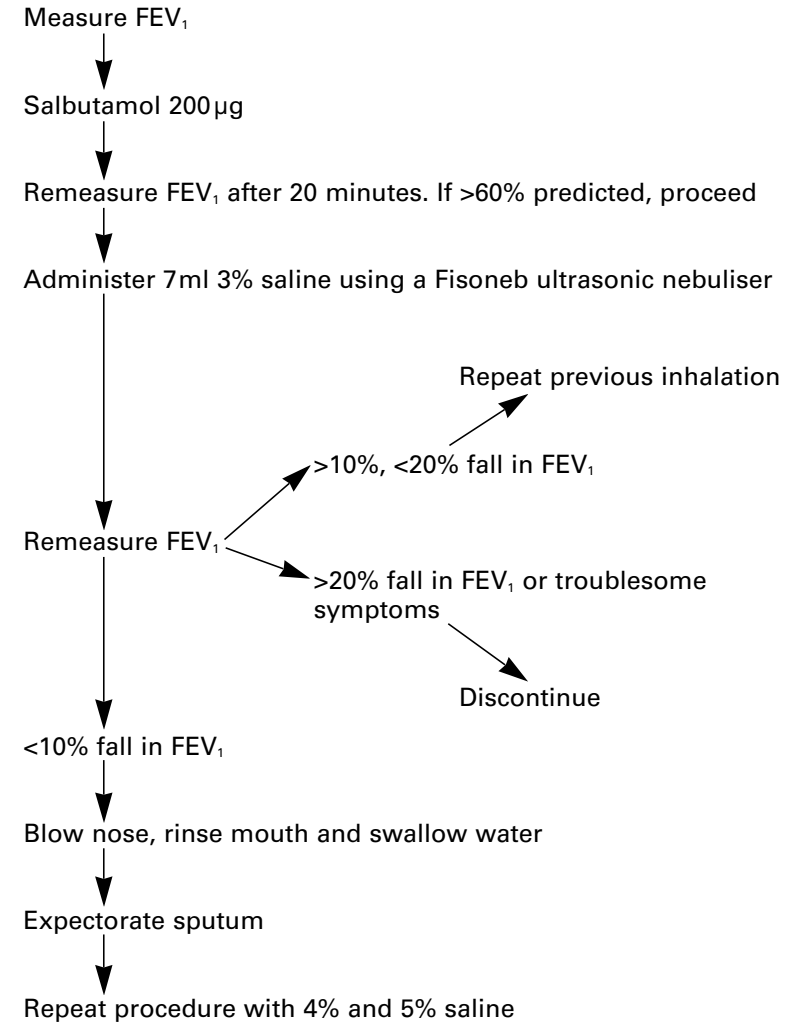

Figure 1 Protocol for sputum induction. 
tions. ${ }^{16}$ In later specimens the cellular changes were consistent with the sputum arising from more distal airways, raising the interesting possibility that it might be possible to measure inflammation selectively in different parts of the tracheobronchial tree. Whether these differences occur with different sputum induction protocols is currently unknown, but until further work is done we recommend that, where possible, the full sputum induction protocol is followed and all the sputum collected is used for cellular and biochemical analysis.

The second important advance has been the use of dithiothreitol (DTT) to improve cell dispersion. ${ }^{917}$ DTT is a sulphydryl reagent which produces mucolysis by opening disulphide bonds which crosslink glycoprotein fibres and maintain sputum in its gel form. ${ }^{17}$ Careful comparisons of sputum selected from saliva and treated with DTT and sputum smears has shown that cell dispersion with DTT is highly effective, making total and differential cell counts easier, quicker, and more reproducible. ${ }^{917}$ Cell definition is improved in DTT treated sputum, enabling differential cell counts to be performed on Wright's stained cytospins without the need for further stains for eosinophils. If a metachromatic cell count is required additional cytospins still need to be stained with toluidine blue. ${ }^{9}$

Cytospins obtained from sputum dispersed with DTT are suitable for immunocytochemical staining of cellular products such as EG-2 reactive protein (a conversion product of eosinophilic cationic protein), granulocytemacrophage colony stimulating factor (GM-CSF), tumour necrosis factor $\alpha(\mathrm{TNF}-\alpha)$, and interleukin (IL)-8. ${ }^{918}$ The sputum supernatant can be used to measure molecular markers which reflect different aspects of airway inflammation ${ }^{19}$ including eosinophil activation (e.g. eosinophilic cationic protein (ECP)), mast cell activation (e.g. tryptase), cytokine production (e.g. IL-5), and microvascular leakage (e.g. albumin and fibrinogen) (table 1). A further exciting possibility is the use of the washed and resuspended cell pellet to study sputum lymphocyte subsets and activation markers by flow cytometry, ${ }^{20}$ although with current methods this technique is limited to patients who are able to generate sufficient sputum. Using a current protocol (fig 2) DTT does not appear to interfere with the assay of ECP, IL-5, fibrinogen, albumin, or tryptase, or appreciably to interfere with immunocytochemical staining of GMCSF, TNF- $\alpha$, IL-8, or most lymphocyte surface markers; it may slightly decrease staining of EG-2 and the human leucocyte antigen HLA-DR. ${ }^{918} 19$

Other investigators have developed different techniques for performing sputum differential cell counts and measuring molecular markers of inflammation in the sputum supernatant. ${ }^{1421}$ The most important difference is whether sputum is selected from the lower respiratory tract or the whole expectorate of sputum plus saliva is processed. Fahy and colleagues have suggested that selection of sputum might lead to loss of potentially relevant information and have advocated processing of the whole expectorate. ${ }^{1421}$ The main disadvantage of this approach is that sputum is

Table 1 Some molecular markers of inflammation measured in the sputum fluid phase by a new reliable technique ${ }^{19}$

\begin{tabular}{lll} 
Marker & Reflecting & Normal range \\
\hline ECP & Eosinophil activation & $288(338) \mu \mathrm{g} / 1$ \\
EDN & Eosinophil activation & $448(376) \mu \mathrm{g} / 1$ \\
MBP & Eosinophil activation & $304(602) \mu \mathrm{g} / 1$ \\
Tryptase & Mast cell activation & $13(11.2) \mathrm{U} / 1$ \\
Albumin & Microvascular leakage & $288(318) \mu \mathrm{g} / \mathrm{ml}$ \\
Fibrinogen & Microvascular leakage & $440(756) \mathrm{ng} / \mathrm{ml}$ \\
\hline
\end{tabular}

$\mathrm{ECP}=$ eosinophilic cationic protein; $\mathrm{EDN}=$ eosinophil derived neurotaxin; $\mathrm{MBP}=$ major basic protein .

Normal ranges derived from 10 normal subjects are quoted as median (interquartile range).
Select sputum (if necessary using inverted microscope)

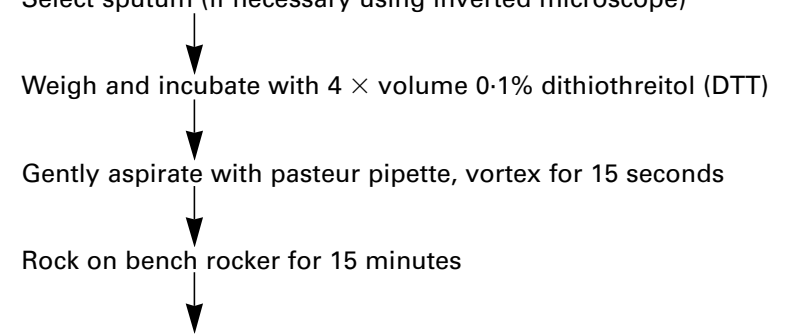

Mix with equal volume (to DTT) of Dulbecco's phosphate buffered saline (D-PBS)

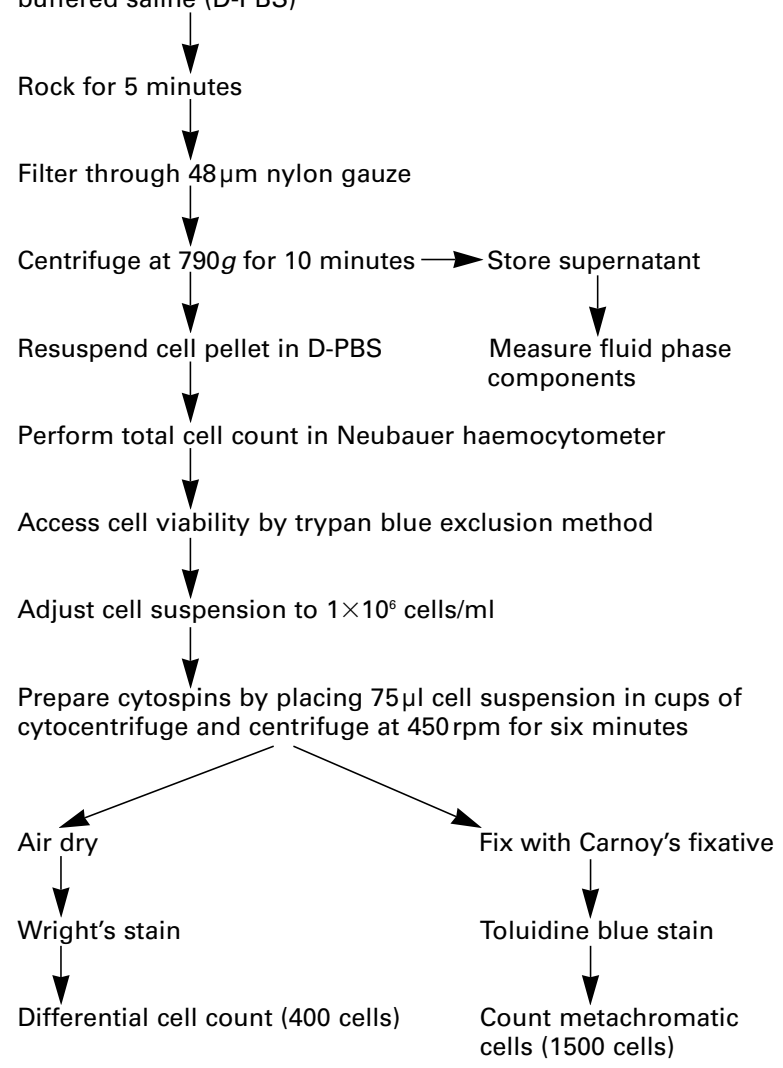

Figure 2 Protocol for sputum processing.

inevitably diluted by saliva and that the extent of this dilution is difficult to quantify accurately. We have recently compared differential cell counts (expressed as a percentage of the non-squamous cells) and fluid phase ECP in selected sputum and in the residual portion ${ }^{22}$ and have shown that differential cell counts do not differ but that the quality of the cytospins is better in the selected portion, principally because of less salivary squamous cell contamination. More importantly, the fluid phase ECP concentration was 5-6 times higher in the selected portion than in the residual portion, suggesting that important dilution does occur in the latter. This interpretation is supported by a recent study showing a negative correlation between ECP concentration in the total expectorate and the extent of salivary contamination as assessed by squamous cell counts. ${ }^{23}$ Our method of selecting sputum from saliva - by removing all more viscous and dense portions with blunt forceps results in a median squamous cell contamination of $1.6 \%{ }^{22}$ so that any effect of salivary dilution is likely to be minimal. So far there is no evidence that relevant information is lost by selection. 
Table 2 Normal ranges for sputum total cell count and differential inflammatory cell counts derived from 10 normal subjects ${ }^{19}$

\begin{tabular}{lcc}
\hline Cell & \multicolumn{2}{l}{ Normal range } \\
\cline { 2 - 3 } & Median & Interquartile range \\
\hline Total cell count & 3.1 & 4.0 \\
$\left(\times 10^{6} / \mathrm{ml}\right)$ & & \\
Eosinophils (\%) & 0.5 & 1.1 \\
Neutrophils (\%) & 24.1 & 26.8 \\
Macrophages (\%) & 62.9 & 30.2 \\
Lymphocytes (\%) & 1.3 & 1.6 \\
\hline
\end{tabular}

\section{Measurements in disease}

We have recently used the new method for sputum induction and processing (figs 1 and 2) to measure cell and fluid phase indices of inflammation in normal subjects and subjects with asthma and non-obstructive chronic bronchitis $^{19}$ and have established normal ranges for these measures (table 2). We have confirmed previous findings using sputum smears on the validity of sputum inflammatory cell counts by showing that eosinophil and metachromatic cell counts tend to be higher in subjects with asthma than in normal and bronchitic subjects, and have shown for the first time that sputum from subjects with asthma contains a slight excess of neutrophils. Sputum inflammatory cell counts are highly repeatable. The within subject repeatability of sputum eosinophil counts in subjects with asthma is such that $95 \%$ of repeated measures lie within a twofold range of the original measurement. ${ }^{19}$ Sputum fluid phase ECP, tryptase, fibrinogen, and albumin concentrations were higher in sputum from subjects with asthma than from normal subjects and were repeatable. ${ }^{18}$ ECP and tryptase concentrations correlated positively with the sputum eosinophil and metachromatic differential cell count, in keeping with their suspected cellular origin (table $1)$.

Sputum cell and fluid phase indices of inflammation were also responsive to change as indicated by an increase in sputum eosinophils, metachromatic cells, tryptase, and ECP after allergen challenge ${ }^{2124}$ and a decrease after treatment with oral and inhaled corticosteroids. ${ }^{2325}$ The difference between normal and asthmatic subjects and the effect of intervention with allergen and corticosteroids are similar in direction but more marked than changes seen in studies using bronchoalveolar lavage, ${ }^{26-28}$ which suggests that sputum yields samples that are representative of events in the lower airway. This assumption is supported by recent studies showing a reasonably close correlation between differential eosinophil counts in sputum and bronchial washings in normal and asthmatic subjects. ${ }^{2930}$ Concentrations of ECP and most other molecular markers of inflammation are considerably higher in sputum than in bronchoalveolar lavage fluid which suggests that sputum is richer in airway secretions than samples obtained by bronchoscopy.

\section{Initial research and clinical applications}

The new reliable methods for obtaining and processing sputum in asthma raise exciting clinical and research possibilities since measurement of cellular and molecular indices of inflammation in sputum represents the only direct and practical way to assess airway inflammation serially in large numbers of patients. One obvious application is to use sputum inflammatory indices to increase our understanding of complex relationships between inflammatory cell and mediator and cytokine mechanisms in asthma. The sputum fluid phase seems to be suitable to measure ECP, some cytokines, and histamine, and may be suitable for measurements of other mediators such as prostanoids or cysteinyl-leukotrienes as initially suggested nearly 20 years ago. ${ }^{31}$ Studies examining release of cytokines and mediators in stable asthma and following intervention with bronchoconstrictor challenge or drugs have thus far been difficult but may be possible since obtaining sputum is non-invasive and can be done serially.

Assessment of airway inflammation using sputum could also be used to evaluate the effects of drugs on asthmatic airway inflammation and to relate their anti-inflammatory effect to the effects on symptoms and disordered airway function. The addition of sputum measurements of inflammation to an allergen challenge adds a powerful new dimension to these studies. This approach has shown that the inhibitory effect of single doses of salmeterol, formoterol, and beclomethasone on the late response to allergen is not associated with a reduction in allergeninduced eosinophilia. ${ }^{2432}$ Longer term treatment with salmeterol also has no effect on the raised sputum eosinophil count compared with placebo in patients with uncontrolled asthma despite improving symptoms and airflow obstruction, whereas an increased dose of inhaled steroid causes a parallel improvement in clinical measures and measures of airway inflammation. ${ }^{25}$ Similar acute and longer term studies would be possible with other drugs with putative anti-inflammatory effects such as theophylline and antileukotrienes. Alternatively, sputum could be used to assess a possible pro-inflammatory effect of chronic treatment with $\beta_{2}$ agonists.

The use of induced sputum to assess airway inflammation in a clinical setting has already led to important increases in our understanding of the relationship between airway inflammation and disordered airway function. Studies have generally not shown a correlation between eosinophilic airway inflammation and airway responsiveness to direct $^{720}$ or indirect ${ }^{33}$ challenge between subjects with asthma, suggesting that the relationship between these features of asthma is more complex than was once thought. However, there is a correlation between the change in airway responsiveness and the change in sputum eosinophil count after allergen challenge ${ }^{6}$ which suggests that within subjects these features are related. The absence of a relationship between eosinophilic airway inflammation and airway hyperresponsiveness between subjects is most strikingly illustrated by the identification of a group of patients with a corticosteroid responsive chronic cough and sputum evidence of a florid eosinophilic bronchitis but normal spirometric values, airway responsiveness to direct and indirect challenge, and peak expiratory flow variability. ${ }^{345}$ Furthermore, a substantial proportion of patients with uncontrolled asthma and considerable airway hyperresponsiveness and variable airflow obstruction have no eosinophilic inflammation. ${ }^{3637}$ Since the available evidence suggests that corticosteroids are considerably more effective when there is evidence of eosinophilic inflammation, ${ }^{2}$ these findings raise important questions about the universal use of increased doses of inhaled corticosteroids or oral corticosteroids in uncontrolled asthma and suggest that knowledge of the nature of the underlying airway inflammation could be used to target additional treatment in uncontrolled asthma.

The use of sputum to assess airway inflammation in conditions other than asthma has not been extensively explored. Non-obstructive chronic bronchitis is associated with a mild sputum neutrophilia but normal eosinophil counts and sputum ECP concentrations, ${ }^{19}$ whereas chronic obstructive pulmonary disease (COPD) is associated with a marked sputum neutrophilia together with increased sputum concentrations of TNF- $\alpha$ and IL-8. ${ }^{38}$ Whether demonstration of a sputum eosinophilia by the new reliable methods in patients with what appears to be COPD iden- 
tifies those with a good response to corticosteroids remains to be determined, although studies using earlier techniques to count sputum inflammatory cells have suggested that this might be the case.${ }^{39}$ Bacterial and viral lower respiratory tract infections, obliterative bronchiolitis, and some cases of sarcoidosis and extrinsic allergic alveolitis are associated with airway inflammation and might be usefully investigated with new sputum techniques.

\section{Conclusions}

In the last eight years there have been considerable advances in the methodology of sputum collection and differential cell counting such that the technique has now evolved to a point where it is repeatable, valid, and responsive and appears to provide meaningful information about inflammatory events in the lower airway. The use of sputum to investigate airway inflammation also has the great advantage of being non-invasive and thus feasible and suitable for repeated measures in most patients. It promises to be a valuable new research technique and in the clinic it offers the prospect for the first time of relating airway inflammation to clinical features, abnormalities of airway function, and treatment response in a large number of patients.

Correspondence to: Dr I D Pavord.

Department of Respiratory Medicine,

I D PAVORD

Glenfield Hospital,

Groby Road,

Leicester LE3 9QP, UK

Asthma Research Group,

St Foseph's Hospital-McMaster University,

Hamilton, Canada

M M M PIZZICHINI E PIZZICHINI

F E HARGREAVE

1 Sakula A. Charcot-Leyden crystals and Curschmann spirals in asthmatic sputum. Thorax 1986;41:503-7.

2 Morrow Brown H. Treatment of chronic asthma with prednisolone. Significance of eosinophils in the sputum. Lancet 1958;ii:1245-7.

3 Holgate S. Mediator and cytokine mechanisms in asthma. Thorax 1992;48: $103-9$.

4 Djukanovic R, Roche WR, Wilson JW, Beasley CRW, Twentyman OP, Howarth PH, et al. Mucosal inflammation in asthma. Am Rev Respir Dis 1990;142:434-57.

5 Gibson PG, Girgis-Gabardo A, Morris MM, Mattoli S, Kay JM, Dolovich $\mathrm{J}$, et al. Cellular characteristics of sputum from patients with asthma and chronic bronchitis. Thorax 1989;44:693-9.

6 Pin I, Frietag AP, O'Byrne PM, Girgis-Garbardo A, Watson RM, Dolovich $\mathrm{J}$, et al. Changes in the cellular profile of induced sputum after allergeninduced asthmatic responses. Am Rev Respir Dis 1992;145:1265-9.

7 Pin I, Gibson PG, Kolendowicz R, Girgis-Gabardo A, Denburg JA, Hargreave $\mathrm{FE}$, et al. Use of induced sputum cell counts to investigate airway inflammation. Thorax 1992;47:25-9.

8 Hargreave FE, Popov T, Kidney J, Dolovich J. Sputum measurements to assess airway inflammation in asthma. Allergy 1993;48:81-3.

9 Popov T, Gottschalk R, Kolendowicz R, Dolovich J, Powers P, Hargreave FE. The evaluation of a cell dispersion method of sputum examination. Clin Exp Allergy 1994;24:778-83.

10 Daviskas E, Anderson SD, Gonda I, Eberl S, Meikle S, Seale JP, et al. Inhalation of hypertonic saline aerosol enhances mucociliary clearance in asthmatic and healthy subjects. Eur Respir f 1996;9:725-32.

11 Pizzichini MMM, Popov T, Pizzichini E, Efthimiadis A, Hussak P, Evans $\mathrm{S}$, et al. Spontaneous and induced sputum to measure indices of airway inflammation in asthma. Am f Respir Crit Care Med 1996;154:866-9.

12 Pizzichini MMM, Pizzichini E, Clelland L, Dolovich J, Hargreave FE. Safety of sputum induction in a severe exacerbation of asthma: influence of prior $\beta_{2}$ agonist (abstract). Eur Respir F 1996;9:188-9s.
13 Popov TA, Pizzichini MMM, Pizzichini E, Kolendowicz R, Punthakee Z, Dolovich $\mathrm{J}$, et al. Some technical factors influencing the induction of sputum for cell analysis. Eur Respir $\mathcal{F}$ 1995;8:559-63.

14 Fahy JV, Liu J, Wong H, Boushey HA. Cellular and biochemical analysis of induced sputum from asthmatic and from healthy subjects. Am Rev Respir Dis 1993;147:1126-31.

15 Boushey HA, Wong HH, Mahlmeister MJ, Fahy JV. Safety of sputum induction in asthmatic subjects (abstract). Am f Respir Crit Care Med 1996;153:A289.

16 Holz O, Jorres RA, Koschyk S, Speckin P, Welker L, Magnussen H. Changes of cellular and biochemical sputum composition during sputum induction in healthy and asthmatic subjects (abstract). Am f Respir Crit Care Med 1996;153:A289.

17 Wooten OJ, Dulfano MJ. Improved homogenization techniques for sputum cytology counts. Ann Allergy 1978;41:150-4.

18 Girgis-Garbardo A, Kanai N, Denburg JA, Hargreave FE, Jordana M, Dolovich J. Immunocytochemical detection of granulocyte-macrophage colony-stimulating factor and eosinophil cationic protein in sputum cells. colony-stimulating factor and eosinophil
Allergy Clin Immunol 1994;93:945-7.

19 Pizzichini E Pizzichini MMM, Efthimiadis A, Evans S, Morris MM Squillace D, et al. Indices of airway inflammation in induced sputum: reproducibility and validity of cell and fluid phase measurements. $A m \mathcal{F}$ reproducibility and validity of cell and

20 Kidney JC, Wong AG, Efthimiadis A, Morris MM, Sears MR, Dolovich J et al. Elevated B cells in sputum of asthmatics. Close correlation with et al. Elevated B cells in sputum of asthmatics. Close
eosinophils. Am F Respir Crit Care Med 1996;153:540-4.

21 Fahy JV, Liu J, Wong H, Boushey HA. Analysis of cellular and biochemical constituents of induced sputum after allergen challenge: a method fo studying allergic airway inflammation. F Allergy Clin Immunol 1994;93: 1031-9.

22 Pizzichini E, Pizzichini MMM, Efthimiadis A, Hargreave FE, Dolovich J. Measurement of inflammatory indices in induced sputum: effect of selection of sputum to minimise salivary contamination. Eur Respir $\mathcal{F} 1996$ 9:1174-80.

23 Claman DM, Boushey HA, Liu J, Wong H, Fahy JV. Analysis of induced sputum to examine the effects of prednisone on airway inflammation in asthmatic subjects. F Allergy Clin Immunol 1994;94:861-9.

24 Pizzichini MMM, Kidney JC, Wong BJO, Morris MM, Efthimiadis A, Dolovich J, et al. Effect of salmeterol compared with beclomethasone on allergen-induced asthmatic and inflammatory responses. Eur Respir $\mathcal{F}$ 1996;9:449-55.

25 Turner MO, Hussack PA, Efthimiadis A, Johnston P, Sears MR, Dolovich $\mathrm{J}$, et al. Sputum to investigate the antiinflammatory effect of salmeterol vs beclomethasone (abstract). Am $\mathcal{A}$ Respir Crit Care Med 1996;153:A293.

26 Beasley R, Roche WR, Roberts JA, Holgate ST. Cellular events in the bronchi in mild asthma and after bronchial provocation. Am Rev Respir Dis 1989;139:806-17.

27 Brusasco V, Crimi E, Gianiorio P, Lantero S, Rossi GA. Allergen-induced increase in airway responsiveness and inflammation in mild asthma. $f$ Appl Physiol 1990;69:2209-14.

28 Duddridge M, Ward C, Hendrick DJ, Walters EH. Changes in bronchoalveolar lavage inflammatory cells in asthmatic patients treated with high dose inhaled beclomethasone dipropionate. Eur Respir f 1993;6:489-97.

29 Fahy JV, Wong H, Liu J, Boushey HA. Comparison of samples collected by sputum induction and bronchoscopy from asthmatic and healthy subjects. Am F Respir Crit Care Med 1995;152:53-8.

30 Maestrelli P, Saetta M, Di Stefano A, Calcagni PG, Turato G, Ruggieri $\mathrm{MP}$, et al. Comparison of leukocyte counts in sputum, bronchial biopsies and bronchoalveolar lavage. Am $\mathcal{F}$ Respir Crit Care Med 1995;152:1926-31

31 Turnbull LS, Turnbull LW, Leitch AG, Crofton JW, Kay AB. Mediator of immediate-type hypersensitivity in sputum from patients with chronic bronchitis and asthma. Lancet 1977;ii:526-9.

32 Wong BJ, Dolovich J, Ramsdale EH, O’Byrne P, Gontovnick L, Denburg JA, et al. Formoterol compared with beclomethasone and placebo on allergen-induced asthmatic responses. Am Rev Respir Dis 1992;146:115660 .

33 Iredale MJ, Wanklyn AR, Phillips IP, Krausz T, Ind PW. Non-invasive assessment of bronchial inflammation in asthma: no correlation between eosinophilia of induced sputum and bronchial responsiveness to inhaled hypertonic saline. Clin Exp Allergy 1994;24:940-5.

34 Gibson PG, Dolovich J, Denburg J, Ramsdale EH, Hargreave FE. Chronic cough: eosinophilic bronchitis without asthma. Lancet 1989;i:1346-8.

35 Gibson PG, Hargreave FE, Girgis-Gabardo A, Morris M, Denburg J, Dolovich J. Chronic cough with eosinophilic bronchitis: examination for variable airflow obstruction and response to corticosteroid. Clin Exp Allergy 1995;25:127-32.

36 Turner MO, Hussack P, Sears MR, Dolovich J, Hargreave FE. Exacerbations of asthma without sputum eosinophilia. Thorax 1995;50:1057-61.

37 Fahy JV, Kim KW, Liu J, Boushey HA. Prominent neutrophilic inflammation in sputum from subjects with asthma exacerbation. $\mathcal{F}$ Allergy Clin Immunol 1995;95:843-51.

38 Keatings VM, Collins PD, Scott DM, Barnes PJ. Differences in interleukin8 and tumor necrosis factor- $\alpha$ in induced sputum from patients with chronic obstructive pulmonary disease or asthma. Am f Respir Crit Care Med 1996;153:530-4

39 Sahn SA. Corticosteroids in chronic bronchitis and pulmonary emphysema Chest 1978;73:389-96. 